\title{
Purification and physico-chemical study of serum albumins of two neotropical fish species from the São Francisco River Bassin, Brazil
}

\author{
Dilson Silva ${ }^{1,3}$, Celia Martins Cortez ${ }^{1}$, Natalia P. Nogueira ${ }^{2}$ \& Frederico Freire da Cunha Bastos ${ }^{2}$ \\ ${ }^{1}$ Universidade do Estado do Rio de Janeiro, Departamento de Matemática Aplicada, Rio de Janeiro, RJ, Brazil. \\ ${ }^{2}$ Universidade do Estado do Rio de Janeiro, Departamento de Bioquímica, Rio de Janeiro, RJ, Brazil. \\ ${ }^{3}$ Corresponding author: Dilson Silva,e-mail: dilsons@uerj.br
}

SIlVA, D., CORTEZ, C.M., NOGUEIRA, N.P., BASTOS, F.F.C. Purification and physico-chemical study of serum albumins of two neotropical fish species from the São Francisco River Bassin, Brazil. Biota Neotropica. 15(3): e20140179. http://dx.doi.org/10.1590/1676-0611-BN-2014-0179

\begin{abstract}
This paper presents results from a study of albumin from pacu (Piaractus mesopotamicus, Holmberg 1887) and the catfish pintado (Pseudoplatystoma corruscans, Spix \& Agassiz, 1829), two neotropical fish species inhabitants of Brazilian rivers, comparing their molecular mass and discussing their secondary structures based on spectropolarimetric (circular dychroism) measurements. Genetic controlled specimens were obtained from two fish hatcheries, located in Mococa (pacu) and in São João da Boa Vista (pintado), both in São Paulo State, Brazil. After a period of adaptation in holding tanks, fish blood samples were taken by punctioning their abdominal aorta. Purified albumin was obtained by gel filtration. SDS-PAGE electrophoresis was performed for the molecular mass estimation. Circular Dichroism spectra were registered for albumins of the two fish species over the range of 190-250 nm (far-UV), which shown two negative bands at 217 and $208 \mathrm{~nm}$, a positive peak at $196 \mathrm{~nm}$ and a crossover at $200 \mathrm{~nm}$. This profile is compatible with proteins that content predominantly alpha-helix structure.
\end{abstract}

Keywords: Spotted sorubim, Pseudoplatystoma corruscans, Pacu, Piaractus mesopotamicus, fish serum albumin, circular dychroism.

SILVA, D., CORTEZ, C.M., NOGUEIRA, N.P., BASTOS, F.F.C. Purificação e estudo físico-químico de albuminas de duas espécies de peixes neotropicais da Bacia do Rio São Francisco, Brasil. Biota Neotropica. 15(3): e20140179. http://dx.doi.org/10.1590/1676-0611-BN-2014-0179

Resumo: Este artigo apresenta os resultados de um estudo sobre as albuminas de pacu (Piaractus mesopotamicus, Holmberg 1887) e pintado (Pseudoplatystoma corruscans, Spix \& Agassiz, 1829), duas espécies neotropicais de peixes nativas do Brasil, determinando as suas massas moleculares e discutindo suas estruturas secundárias, com base em medidas de espectropolarimetria (dicroísmo circular). Espécimes controlados geneticamente foram obtidos de duas diferentes pisciculturas, uma localizada na cidade de Mococa (pacu) e a outra, na cidade de São João da Boa Vista (pintado), ambas no Estado de São Paulo, Brasil. Após um período de adaptação em tanques apropriados, amostras de sangue foram coletadas por punção da aorta abdominal dos peixes. Albumina pura foi obtida por gel filtração dessas amostras e as massas moleculares foram determinadas a partir dos dados da eletroforese SDS-PAGE. Espectros de dicroísmo circular das albuminas dos peixes foram registrados na região de 190-250 nm (far-UV), os quais mostraram duas bandas negativas, a 217 e $208 \mathrm{~nm}$, um pico positivo a $196 \mathrm{~nm}$ e um crossover a $200 \mathrm{~nm}$; perfil este compatível com proteínas que contem predominantemente estrutura alfa-hélice.

Palavras-chave: Albumina de peixe, Pintado, Pseudoplatystoma corruscans, Pacu, Piaractus mesopotamicus, dicroísmo circular.

\section{Introduction}

Among of transport proteins in blood plasma, only albumin is able to bind a wide diversity of drugs reversibly with high affinity. Albumin is typically the major anionic protein in vertebrate plasma, representing more than $52 \%$ of the total plasmatic protein content. It has an important role in transport endogenous ligands and xenobiotics mostly through the formation of non-covalent complexes at specific binding sites. Albumin also plays an essential role in organisms when protects them by binding toxic metabolites, such as bilirubin, as well as functioning as a reservoir of the nitric oxide (Kragh-Hansen 1990; Curry et al. 1998; Sugio et al. 1999; Bertucci and Domenici 2002; Stamler et al. 1992). According to Shao et al. (1993), this protection function presents a special importance in the Chinese cobra, since serum albumin avoids that the snake becomes victim from its own venom. 
The study of albumins represents a challenge as they have not a single property by which they can be identified (Maillou and Nimmo 1993). Much data about quantity and structure of mammalian albumins, mainly bovine (BSA) and human (HSA) serum albumin, can be found in literature (Silva et al. 2004a, 2004b, 2004c, Bertucci and Domenici 2002, Kragh-Hansen 1990), but very few information about fish albumin is available (Silva et al. 2009a, 2009b). The shortage of data about fish albumin makes to establish a pattern a difficult task, even so for the same family (Perrier et al. 1974, Davidson et al. 1989). However, it is known that, in general, these proteins have at least one residue of tryptophan (Feller et al. 1994) along their chain.

In this study we have isolated, purified, and studied albumin from pacu (Piaractus mesopotamicus, Holmberg 1887) and pintado (Pseudoplatystoma corruscans, Spix \& Agassiz 1829), two neotropical fish species inhabitants of Brazilian rivers, obtained from fish hatcheries located in São Francisco River basin in São Paulo State, Brazil, establishing their molecular mass and discussing their secondary structures based on spectropolarimetric (circular dychroism, CD) measurements.

\section{Material and Method}

Genetic controlled early specimens of pacu and pintado, $\mathrm{wt}=300 \pm 15 \mathrm{~g}$, were obtained from two fish hatcheries, one located in Mococa (pacu) and another in São João da Boa Vista, both in São Paulo State, Brazil. They were supplied with well-aerated water (normoxic conditions) in holding tanks at constant temperature of about $28^{\circ} \mathrm{C}$. After an adaptation period, they were used in experiments. Fish were fed with commercial feed pellets. Blood samples were taken from the abdominal aorta of live fish using non-heparinzed syringes.

Serum from fish blood was previously treated with ammonia sulfate, dialyzed, and chromatographed in blue sepharose affinity column. Purified albumin was obtained by gel filtration. SDS-PAGE electrophoresis was performed for molecular mass estimation.

The chromatographic method used was that described by Travis and Pannell (1973). Serum was applied to a HiTrap Blue column, and fractionated with $50 \mathrm{mM}$ potassium phosphate pH 7.4 at $2 \mathrm{ml} / \mathrm{min}$, monitoring the absorbance at $280 \mathrm{~nm}$. After discarding non-bound fractions, albumin was washed out with a gradient of 0 to $1.5 \mathrm{M}$ of elution buffer $(\mathrm{KCl}$ in phosphate buffer). Total serum protein concentration was determined using the Peterson's method (Peterson 1977) and albumin serum concentration was determined by the Basil Doumas method (Doumas et al. 1971).

To study the secondary structure of albumin we used the spectrospolarimetric method within the $\mathrm{CD}$ technique. CD spectra were registered over the range of 190-250 nm (far-UV).

\section{Results and Dicussion}

Gel filtration and electrophoresis showed a molecular weighs for both pacu and pintado albumins, around $66 \mathrm{kDa}$, presenting strong similarity to BSA. These results agree to the values considered by Maillou and Nimmo (1993), who suggested that the molecular weigh of fish albumin can be next to $70 \mathrm{kDa}$, basing on their electrophoretic analysis using serum of two different species of fish. For two members of the
Salmonidae family, the chinook salmon (Oncorhynchus tshawytscha) and brown trout (Salmo trutta), Brennan et al. (1998) found molecular masses of 65 and $67 \mathrm{kDa}$ for Salmon and trout albumins, respectively.

The total serum protein concentrations measured by Peterson's method (1977) were $16 \mathrm{mg} / \mathrm{ml}$ and $34 \mathrm{mg} / \mathrm{ml}$ for pintado and pacu, respectively. By means of the brome cresol green method, we determined albumin fractions of $1.6 \mathrm{mg} / \mathrm{ml}$, for pintado, and $2.0 \mathrm{mg} / \mathrm{ml}$, for pacu. These values are in accordance to the suggestion that serum albumin concentration in fishes can be much lower than of albumin concentration in mammals, which vary from 30 to $40 \mathrm{mg} / \mathrm{ml}$. Due to the low plasmatic ratio, it was thought in the past that albumin was not present in fish serum. But, experiments performed by Byrnes and Gannon (1992) identified cDNA sequences of Salmo salar albumin, and its homology with albumins of others vertebrates was already demonstrated (Metcalf et al. 1998).

In recent study, Zhang et al. (2013) studied the total protein content in plasma from six kinds of mammals and fish and purified albumin. They found that total plasma protein and albumin content in mammals were nearly two times and four times higher than that in fish, respectively. For salmon and trout albumins, values of plasmatic concentration estimated were approximately $15 \mathrm{mg} / \mathrm{ml}$ in both species (Brennan et al. 1998).

The values of albumin concentration we found for the two fish were lower than those found for others fish species. To explain this large variation grade, it is important consider that fishes form the largest group among vertebrates with a wide variability of shapes, dimensions, and anatomical and metabolic characteristics. Physiologically, such variability reflects the great capacity of adaptation of the group to the aquatic environment diversity (Roberts 1981). Pacu and Pintado are two neotropical fresh water fish species, adapted naturally to quite different habitats from those salt and cold water fish species studied by the majority of the authors. On the other hand, pacu and pintado have different nutritional and living habits from each other. While pacu is omnivorous, feeding themselves of plants and fruits, pintado is a benthic carnivorous specie. It might explain the difference we found in their serum protein concentration.

Despite the different concentrations, the CD spectra show similar secondary structure profile for two fish species. Figure shows $\mathrm{CD}$ spetra of pacu and pintado, respectively, obtained at $25^{\circ} \mathrm{C}$ (50 mM phosphate buffer, $\left.\mathrm{pH} 7.4\right)$. These spectra were registered over the range of 190-250 $\mathrm{nm}$ (far-UV), and they present two negative bands at 217 and $208 \mathrm{~nm}$, a positive peak at $196 \mathrm{~nm}$ and a crossover at $200 \mathrm{~nm}$. Selcon 3 method was used for estimating the albumin secondary structure content (Table 1), and the data analysis has shown the spectrum profiles are compatible with proteins that content predominantly alpa-helix structure.

We believe that fish plasmatic proteins can function as an effective biomarker, since their concentration can vary as reflex of nutritional, physiological and/or geographic conditions. In addition, the total and relative ratio of serum protein can be affected by pathological conditions and besides the presence of environmental stressors (Grasman et al. 2000, Ellsaesser and Clem 1987). Fishes can also exhibit polyploidy, responsible for many of the variations in plasma proteins (Komatsu et al. 1970). Thus, we see a high importance in studies about serum 

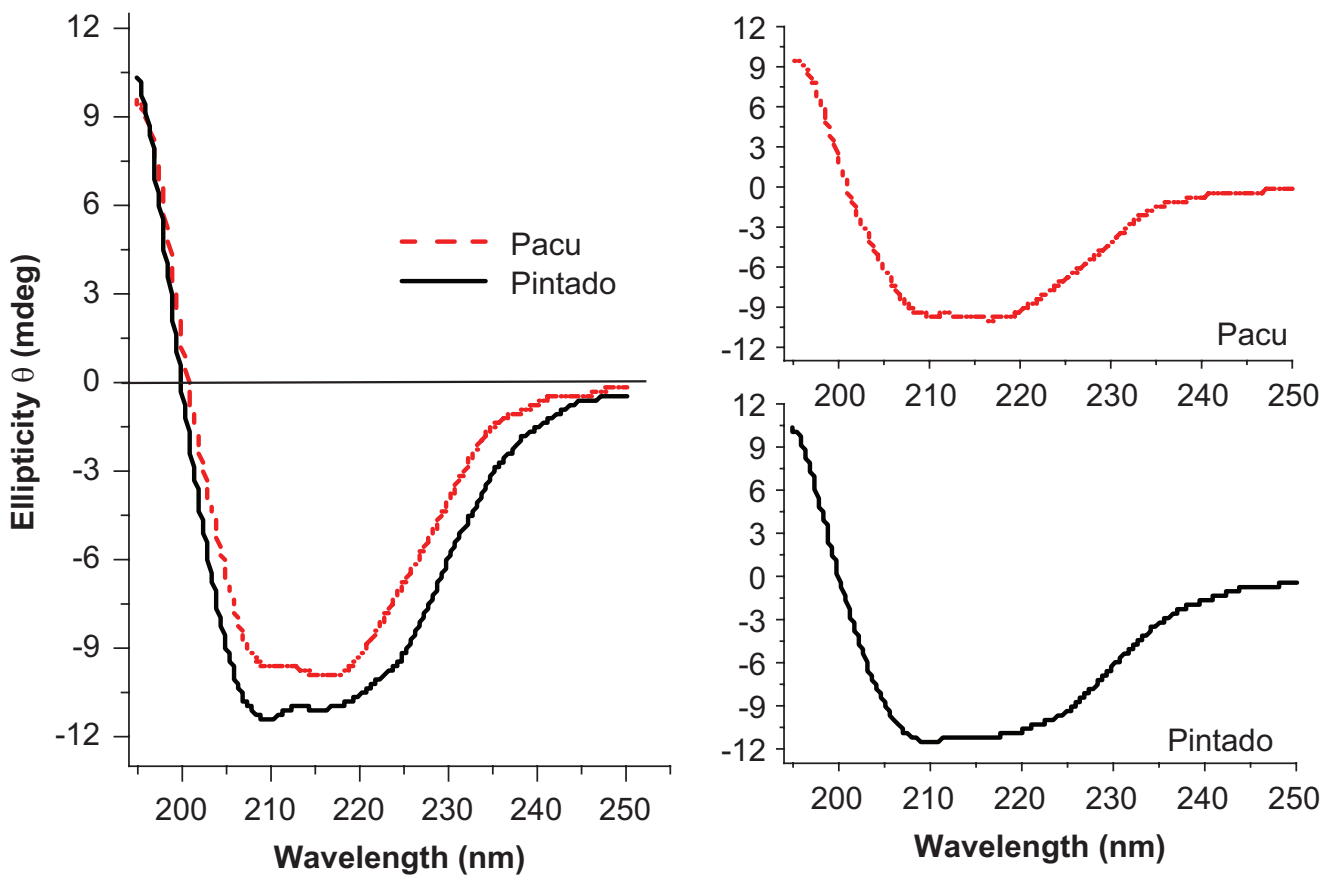

Figure. CD spectrum between 195 e 250 of albumin for Pacu and Pintado at $25^{\circ} \mathrm{C}, 50 \mathrm{mM}$ phosphate buffer, $\mathrm{pH}$ 7.4.

Table 1. Secondary structure content for pacu and pintado serum albumin

\begin{tabular}{lcccc}
\hline & Alpha-helix & Beta-helix & Beta-turn & Unrd \\
\hline Pacu & 49 & 9 & 16 & 25 \\
Pintado & 41 & 12 & 20 & 27 \\
\hline
\end{tabular}

Unrd $=$ disordered.

fish proteins and their interactions, because these data could be of particular interest in ecotoxicology and environmental risk assessment.

\section{Conclusions}

Our results allow conclude that: (1) total serum protein concentrations of pintado and pacu are $16 \mathrm{mg} / \mathrm{ml}$ and $34 \mathrm{mg} / \mathrm{ml}$, respectively; (2) serum concentration of albumin in fish $(1.6 \mathrm{mg} / \mathrm{ml}$, for pintado, and $2.0 \mathrm{mg} / \mathrm{ml}$, for pacu) is very lower than albumin concentration in mammalian; (3) the molecular mass for pacu and pintado serum albumin are about $66 \mathrm{kDa}$, presenting similarity to BSA; (4) the secondary structure content analysis by Selcon 3 method shows predominantly alpha-helix profile for two fish species studied; and (5) CD negative band at $217 \mathrm{~nm}$ suggests difference in its conformation when compared to BSA and HSA.

\section{References}

BERTUCCI, C. \& DOMENICI, E. 2002. Reversible and covalent binding of drugs to human serum albumin: Methodological approaches and physiological relevance. Curr. Med. Chem. 9: 1463-1481, http://dx.doi.org/10.2174/0929867023369673.

BYRNES, L. \& GANNON, F. 1992. Sequence analysis of a second cDNA encoding Atlantic salmon (Salmo salar) serum albumin. Gene 120: 319-320, http://dx.doi.org/10.1016/0378-1119(92)90115-6.
CURRY, S., MANDELKOW, H., BRICK, P. \& FRANKS, N. 1998. Crystal structure of human serum albumin complexed with fatty acid reveals an asymmetric distribution of binding sites. Nat. Struct. Biol. 5: 827-835, http://dx.doi.org/10.1038/1869.

DAVIDSON, W.S., BARTLETT, S.E., BIRT, T.P. \& GREEN, J.M. 1989. Identification and purification of serum albumin from rainbow trute (Salmo gairdneri). Comp. Biochem. Physiol. 93B: 5-9.

DOUMAS, T., WATSON, W.A. \& BIGGS, H.G. 1971. Albumin standards and the measurement of serum albumin with bromocresol green. Clin. Chim. Acta. 31: 87-96, http://dx.doi.org/10.1016/ 0009-8981(71)90365-2.

ELLSAESSER, C. \& CLEM, L.W. 1987. Blood serum chemistry measurements of normal and acutely stressed channel catfish. Comp. Biochem. Physiol. 88A: 589-594, http://dx.doi.org/10.1016/0300-9629(87)90087-9.

FELlER, G., PONCIN, A., AITTALEB, N., SCHYNS, R.E. \& GERDAY, C.H. 1994. The Blood proteins of the Antarctic ice fish Channichthys rinoseratus: biological significance and purification of the two main components. Comp. Biochem. Physiol. 109B: 89-97.

GRASMAN, K.A., Armstrong, M., Hammersley, D.L., Scanlon, P.F. \& Fox, G.A. 2000. Geographic variation in blood plasma protein concentrations of young herring gulls (Larus argentatus) and Caspian terns (Sterna caspia) from the Great Lakes and Lake Winnipeg. Comp. Biochem. Physiol. 125C: 365-375.

KOMATSU, S.K., MILLER, H.T., DEVRIES, A.L., OSUGA, D.T. \& FEENEY, R.E. 1970. Blood plasma proteins of cold-adapted antarctic fishes. Comp. Biochem. Physiol. 32: 519-527, http://dx.doi.org/ 10.1016/0010-406X(70)90469-X.

KRAGH-HANSEN, U. 1990. Structure and ligand binding properties of human serum albumin. Dan. Med. Bull. 37: 57-84.

MAILLOU, J. \& NIMMO, I.A. 1993. Identification and some properties of an albumin-like protein in the serum of pre-spawning Atlantic salmon (Salmo salar). Comp. Biochem. Physiol. 104B: 401-405.

METCALF, V., BRENNAN, S., CHAMBERS, G. \& GEORGE, P. 1998. The albumins of Chinook salmon (Oncorhynchus tshawytscha) and Brown trout (Salmo trutta) appear to lack a propeptide. Arch. Bioch. Biophys. 350: 239-244, http://dx.doi.org/10.1006/abbi.1997.0509.

PERRIER, H., DELCROIX, J.P., PERRIER, C. \& GRASS, J. 1974. Disc electrophoresis of plasma proteins of fish; localization of fibrinogen, transferrin and ceruloplasmin in the plasma of the 
Silva, D. et al.

rainbow trout (Salmo gairdnerii richardson). Comp. Biochem. Physiol. 49B: 679-668.

PETERSON, G.L. 1977. Simplification of protein assay method of Lowry at. al. which is more generally applicable. Anal. Biochem. 83: 346-356, http://dx.doi.org/10.1016/0003-2697(77)90043-4.

ROBERTS, R.J. 1981. Patologia de los peces, cap.I. Ed. MundiPrensa, Madrid.

SHAO, J., SHEN, H. \& HAVSTEEN, B. 1993. Purification, characterization and binding interactions of the Chinese-cobra (Naja naja atra) serum antitoxic protein CSAP. Biochem. J. 293: 559-566, http://dx.doi.org/10.1042/bj2930559.

SILVA, D., CORTEZ, C.M., BASTOS, J.C. \& LOURO, S.R.W. 2004c. Methyl parathion interaction with human and bovine serum albumin. Toxicology Lett 147: 53-61, http://dx.doi.org/10.1016/j. toxlet.2003.10.014.

SILVA, D., CORTEZ, C.M. \& LOURO, S.R.W. 2004a. Chlorpromazine interactions to sera albumins. A study by the quenching of fluorescence. Spectrochim. Acta A: Mol. Biomol. Spectr. 60: 1215-1223, http://dx.doi.org/10.1016/j.saa.2003.08.003.

SILVA, D., CORTEZ, C.M. \& LOURO, S.R.W. 2004b. Quenching of the Intrinsic Fluorescence of Albumin by Chlorpromazine and Hemin. Braz. J. Med. Biol. Res. 37: 963-968.

SILVA, D., CORTEZ-MOREIRA, M., CUNHA-BASTOS, V.L.F., CUNHA-BASTOS, J. \& CORTEZ, C.M. 2010b. Spectroflurimetric
Study of the Interaction of Methyl-parathion with Fish Serum Albumin. Fish. Physiol. Bioch. 36: 427-433, http://dx.doi.org/ 10.1007/s10695-009-9312-z.

SILVA, D., CORTEZ-MOREIRA, M., CUNHA-BASTOS, V.L.F., CUNHA-BASTOS, J.C. \& CORTEZ, C.M. 2010a. The Interaction of Methyl-parathion with Serum and Alabumin of the Neotropical Fish Piaractus mesopotamicus. Ecotoxicol. Environ. Saf 73: 32-37, http://dx.doi.org/10.1016/j.ecoenv.2009.09.003.

STAMLER, J.S., SINGEL, D.J. \& LOSCALZO, J. 1992. Biochemistry of nitric oxide and its redox-activated forms. Proc. Natl. Acad. Sci. USA. 89: 444-448, http://dx.doi.org/10.1073/pnas.89.1.444.

SUGIO, S., KASHIMA, A., MOCHIZUKI, S., NODA, M. \& KOBAYASHI, K. 1999. Crystal structure of human serum albumin at $2.5 \AA$ resolution. Protein. Eng. 12: 439-446, http://dx.doi. org/10.1093/protein/12.6.439.

TRAVIS, J.E. \& PANNELL, R. 1973. Selective removal of albumin from plasma by affinity. Chromatography. Clin. Chim. Acta. 49: 40-52, http://dx.doi.org/10.1016/0009-8981(73)90341-0.

ZHANG, W., LIANG, G., WU, L., TUO, X., WANG, W., CHEN, J. $\&$ XIE, P. 2013. Why mammals more susceptible to the hepatotoxic microcystins than fish: evidences from plasma and albumin protein binding through equilibrium dialysis. Ecotoxicology 22: 1012-1019, http://dx.doi.org/10.1007/s10646-013-1086-5. 